\title{
The Influence of Leadership Style and Organizational Culture by Mediating Job Satisfaction on Organizational Commitment Case Study in Employees Of Islamic Education Institution
}

\author{
Fatmah Bagis $^{1)}$, Akhmad Darmawan ${ }^{2)}$, Arini Hidayah ${ }^{3)}$, Mastur Mujib Ikhsani4) \\ ${ }^{1,2,3,4}$ Faculty of Economics and Business, Universitas Muhammadiyah Purwokerto, Indonesia \\ **Email correspondence: fatmahbagis@ump.ac.id
}

\begin{abstract}
This study aims to describe the influence of leadership style and organizational culture with the mediating variables of job satisfaction on organizational commitment. This study uses a case study method for employees of educational institutions in Purwokerto. Respondents in this study were 74 employees from management level to staff level. PLS (Partial Least Square) analysis using SmartPLS 3.0 is the analysis technique used in this study. The results obtained are first, Leadership Style has no significant effect on Job Satisfaction. Second, Organizational Culture has a significant effect on Job Satisfaction, and Third, Job Satisfaction has a significant effect on Organizational Commitment. Based on the research results prove that Job Satisfaction can only mediate the relationship between Organizational Culture and Organizational Commitment while the relationship between Leadership Style and Organizational Commitment cannot be mediated by Job Satisfaction.
\end{abstract}

Keywords: leadership style, organizational culture, job satisfaction, organizational commitment

\begin{abstract}
Abstrak
Penelitian ini menjelaskan tentang gaya kepemimpinan dan budaya organisasi dan pengaruhnya terhadap komitmen organisasi, di mana kepuasan kerja digunakan sebagai variabel mediasi. Metode yang digunakan dalam penelitian ini adalah studi kasus pada karyawan lembaga pendidikan di Purwokerto. Kuisioner diberikan kepada 74 karyawan dari level manajemen hingga level staf sebagai responden. Teknik analisis data yang digunakan adalah analisis PLS (Partial Least Square) menggunakan SmartPLS 3.0. Hasil penelitian menunjukkan bahwa Gaya Kepemimpinan tidak berpengaruh signifikan terhadap Kepuasan Kerja, tetapi Organisasi Budaya memiliki pengaruh signifikan terhadap Kepuasan Kerja, dan Kepuasan Kerja memiliki pengaruh signifikan terhadap Komitmen Organisasi. Ini juga membuktikan bahwa Kepuasan Kerja dapat memediasi hubungan antara Organisasi Budaya dan Komitmen Organisasi tetapi tidak dapat memediasi hubungan antara Gaya Kepemimpinan dan Komitmen Organisasi.
\end{abstract}

Kata kunci: organisasi budaya, kepuasan kerja, gaya kepemimpinan, komitmen organisasi

Citation Suggestions: Bagis, F., Darmawan, A., Hidayah, A., \& Ikhsani, M. M. (2020). The Influence of Leadership Style and Organizational Culture by Mediating Job Satisfaction on Organizational Commitment Case Study in Employees Of Islamic Education Institution. Jurnal Ilmiah Ekonomi Islam, 6(03), 616-620. doi:http://dx.doi.org/10.29040/jiei.v6i3.1450

DOI: http://dx.doi.org/10.29040/jiei.v6i3.1450

\section{INTRODUCTION}

Educational organizations, in this case, the university is one form of education service organization for the community by providing comprehensive and integrated services that include learning efforts. To create quality education services can not be separated from the role of human resources with motivation, behavior, knowledge, and abilities that support the effectiveness of service realization. Human resources have a role and a very important part of achieving organizational goals. Therefore we need reliable human resources to overcome new challenges, for that we need to increase the potential, skills, and other factors inherent in humans by developing human resources. The development of human resources aims 


\section{Jurnal Ilmiah Ekonomi Islam, 6(03), 2020, 617}

to produce a workforce that is strong and of high quality in carrying out its work.

An organization needs a leader who can bring a company or organization to maintain consistency and be able to compete in the business world. This is related to the important role of a leader in achieving the vision and mission of the organization. Organizations need strong leadership for optimal effectiveness (Robbins, 2008)

(O’Reilly \& Chatman, 1986) (Supomo \& Indriantoro, 1998), (Ashari, 2013) shows that peopleoriented organizational culture reinforces (moderates) the effect of budgeting participation on managerial performance. (Suweno \& Rahadhini, 2012) found that human-oriented organizational culture (human relations) strengthens (moderates) the effect of transformational leadership on employee performance. (Francesco \& Chen, 2004) found that collectivist culture orientation moderates (strengthens) the effect of organizational commitment on employee performance in pharmaceutical companies in China.

(Sinambela,2016) job satisfaction shows that there is a match between someone's expectations that arise with the available rewards so that job satisfaction is also related to justice. Based on previous research that examines organizational commitment which is influenced by job satisfaction (Bagis, 2018). Employee commitment will determine the success of organizational performance. (Shore \& Martin, 1989) stated that organizational commitment can be seen from employee loyalty to the organization and their involvement in the organization. (Lambert et al., 2002) stated that organizational commitment is a bond with the entire organization, workgroup, or belief in the importance of the work itself, and not just the job.

Based on the description in the introduction and research objectives, some of the hypotheses that we can formulate are as follows:

H1: Leadership style has a positive effect on job satisfaction.

H2: Cultural Organization has a positive effect on job satisfaction.

H3: Job satisfaction has a positive effect on organizational commitment.

H4a: Job satisfaction mediates the relationship between leadership style and organizational commitment.
H4b: Job satisfaction mediates the relationship between a cultural organization and organizational commitment.

\section{METHOD}

The quantitative approach is the approach used in this study. This study used a survey method using a self-report questionnaire that was given personally to employees of an educational institution in Purwokerto. The collected questionnaires were obtained from 74 employees from management level to staff level. Partial least squares (PLS) analysis is an analysis of the data used in this study.

a. Leadership Style

(Judge \& Locke, 1993) states that leadership style is one of the determinants of job satisfaction. If a leader applies a leadership style that can create a conducive atmosphere then it can encourage the level of employee job satisfaction, employees will feel more comfortable. Leadership has a major role in trying to understand group behavior because it is the leader who usually provides direction for achieving the goals (Robbins \& Judge, 2008)

b. Cultural Organization

Organizational culture is a form of an implicit assumption that the group has that will be accepted by the group, and can determine how the group feels, thinks, and reacts to its various environments. (Kreitner \& Knicki, 2005).

c. Job Satisfaction

Based on (Locke, 1969), job satisfaction is a pleasant or positive emotional state that can be generated based on the results of a job appraisal or a person's work experience. According to (Brayfield \& Rothe, 1951), job satisfaction can be measured using nineteen items developed by him.

\section{d. Organizational Commitment}

According to (O'Reilly \& Chatman, 1986), organizational commitment is the psychological attachment that a person feels to the organization; It will reflect the degree to which individuals internalize or monitor organizational relationships or perspectives. 


\section{RESULT AND DISCUSSION \\ Hypothesis Testing}

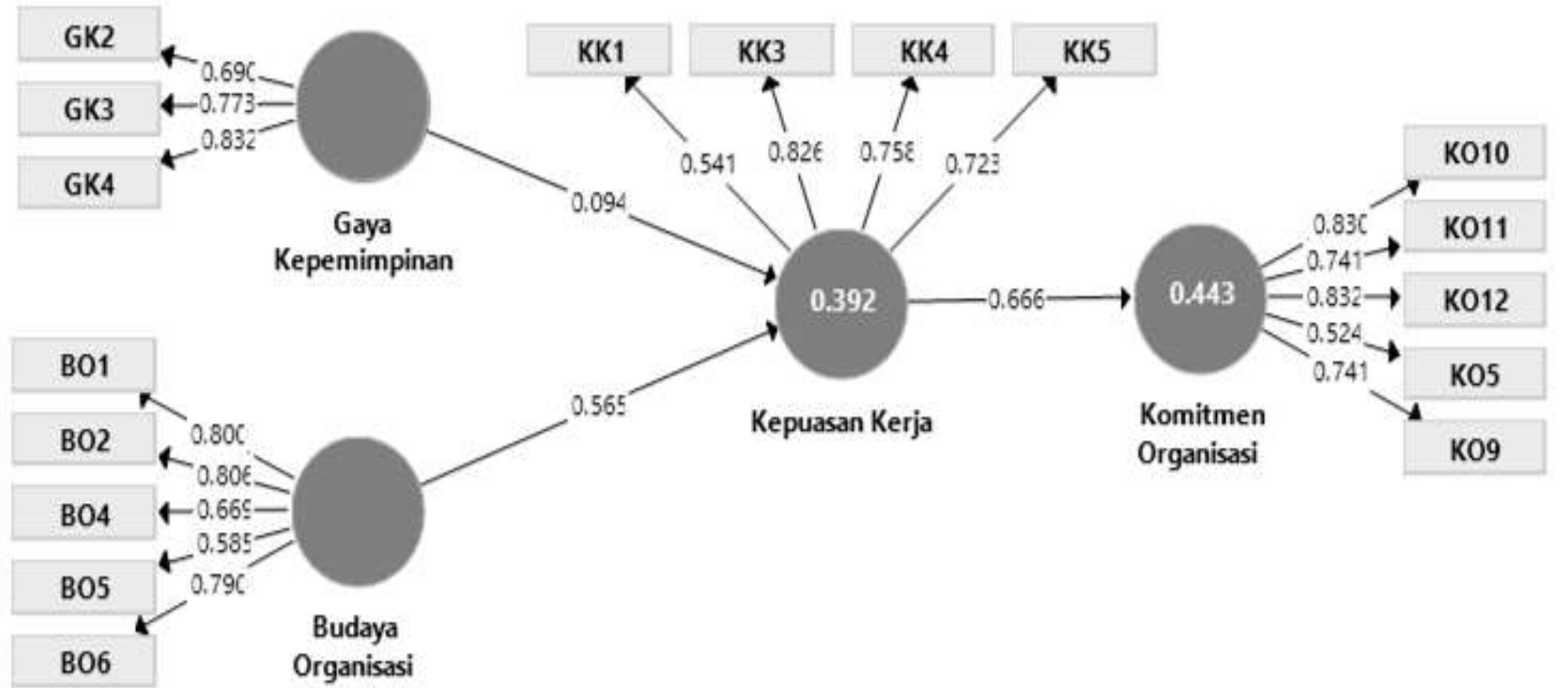

This study uses hypothesis testing with a significance level of $95 \%(\alpha=0.05)$. Based on the results of the Partial Least Square (PLS) analysis, it shows that leadership style does not have a significant effect on job satisfaction, and the first hypothesis which states that leadership style has a significant effect on job satisfaction, then this hypothesis is not accepted.

\section{Table 1. Parameter Coefficient and Statistical Values among Variables}

\begin{tabular}{lccccc}
\hline & $\begin{array}{c}\text { Original } \\
\text { Sample (O) }\end{array}$ & $\begin{array}{c}\text { Sample } \\
\text { Mean (M) }\end{array}$ & $\begin{array}{c}\text { Standard } \\
\text { Deviation } \\
\text { (STDEV) }\end{array}$ & $\begin{array}{c}\text { T Statistics } \\
(\mid \mathrm{O} / \mathrm{STDEV} \\
\mid)\end{array}$ & P Values \\
\hline $\begin{array}{l}\text { Culture organization -> Job } \\
\text { Satisfaction }\end{array}$ & 0,565 & 0,561 & 0,149 & 3,797 & 0 \\
\hline $\begin{array}{l}\text { Leadership Style -> Job } \\
\text { Satisfaction }\end{array}$ & 0,094 & 0,124 & 0,116 & 0,809 & 0,419 \\
\hline $\begin{array}{l}\text { Job Satisfaction -> } \\
\text { Organizational Commitment }\end{array}$ & 0,666 & 0,682 & 0,058 & 11,554 & 0 \\
\hline
\end{tabular}

The results of the Partial Least Square (PLS) analysis show that organizational culture has a significant effect on job satisfaction, so the second hypothesis which states that if the organizational culture has a significant effect on job satisfaction, the hypothesis is accepted. The result of the loading factor value is 0.565 which means that $56.5 \%$ of job satisfaction can be explained by organizational culture.
Based on the results of the Partial Least Square (PLS) analysis, it can be seen that job satisfaction has a significant effect on organizational commitment, and the third hypothesis which states that job satisfaction has a significant effect on organizational commitment, the hypothesis is accepted. The result of the calculation of the factor loading value is 0.666 which means that $66 \%$ of organizational commitment can be explained by job satisfaction. 
Table 2. Result of Sobel Test

Leadership style $\rightarrow$ Job Satisfaction $\rightarrow \quad$ Cultural Organization $\rightarrow$ Job Satisfaction $\rightarrow$ Org. Commitment

Org. Commitment

\begin{tabular}{lrr}
\hline $\mathrm{A}$ & 0,094 & 0.565 \\
$\mathrm{~B}$ & 0.666 & 0.666 \\
$\mathrm{SE}_{\mathrm{A}}$ & 0.116 & 0.149 \\
$\mathrm{SE}_{\mathrm{B}}$ & 0.058 & 0.058 \\
Sobel Test & 0.80833449 & 3.60069479 \\
Statistic & & \\
One-tailed prob. & 0.20944903 & $0.00015868^{*}$ \\
Two-tailed prob. & 0.41889805 & $0.00031737^{*}$ \\
\hline
\end{tabular}

The Sobel test used in this study is to determine whether the mediator variable significantly influences the independent variable on the dependent variable. Based on the Sobel Test results in Table 2, it can be concluded that job satisfaction can only mediate the relationship between organizational culture and organizational commitment, while on the other hand job satisfaction cannot mediate the relationship between leadership style and organizational commitment.

\section{CONCLUSION}

Leadership style does not have a significant effect on job satisfaction of employees of educational institutions, meaning that leadership style does not affect work behavior such as satisfaction. This study also provides results that job satisfaction is not able to be a mediating variable of leadership style on organizational commitment. This can explain that the current employee is comfortable working and has organizational commitment and job satisfaction but is not influenced by the existing leadership style.

Job Satisfaction has a significant effect on employee organizational commitment in educational institutions. This shows that employees will have a higher commitment to the university if they are more satisfied with their work.

Organizational culture has a significant influence on job satisfaction, and job satisfaction can be a mediating variable of the influence between cultural organizations on organizational commitment. Employees currently work with the cultural values obtained and developed by the organization with habits in a situation where employees favor the organization and work so that organizational goals can be achieved.
It is expected that further research will research by changing the existing framework in this research, namely using the leadership style variable and organizational culture as a mediating variable to find out how the actual employee job satisfaction with organizational commitment.

\section{REFERENCES}

Ashari, B. (2013). Pengaruh Partisipasi Penyusunan Anggaran Terhadap Kinerja Manajerial Dengan Budaya Organisasi dan Struktur Organisasi Sebagai Variabel Moderating (Studi Empiris pada SKPD di Kabupaten Agam). Jurnal Akuntansi, 1(3), 1-32.

Bagis, F. (2018). Does Job Satisfaction Mediate the Effect of Procedural Justice and Distributive Justice on Organizational Commitment?: Case Study of Education Institution. 231(Amca), 341344. https://doi.org/10.2991/amca-18.2018.93

Brayfield, A. H., \& Rothe, H. F. (1951). An Index of Job Satisfaction. Journal of Applied Psychology, $35(5)$,

307-311. https://doi.org/10.1037/h0055617

Francesco, A. M., \& Chen, Z. X. (2004). Collectivism in action: Its moderating effects on the relationship between organizational commitment and employee performance in China. Group and Organization Management, 29(4), 425-441. https://doi.org/10.1177/1059601103257423

Judge, T. A., \& Locke, E. A. (1993). Effect of Dysfunctional Thought Processes on Subjective Well-Being and Job Satisfaction. Journal of Applied Psychology, 78(3), 475-490. https://doi.org/10.1037/0021-9010.78.3.475 
Jurnal Ilmiah Ekonomi Islam, 6(03), 2020, 620

Kreitner dan Knicki. 2005. Perilaku Organisasi. Salemba Empat. Jakarta.

Lambert, E. G., Hogan, N. L., \& Barton, S. M. (2002). Satisfied Correctional Staff. Criminal Justice and Behavior, 29(2), 115-143. https://doi.org/10.1177/0093854802029002001

Locke, E. A. (1969). What is job satisfaction? Organizational Behavior and Human Performance, 4(4), 309-336. https://doi.org/10.1016/0030-5073(69)90013-0

O'Reilly, C., \& Chatman, J. (1986). Organizational Commitment and Psychological Attachment. The Effects of Compliance, Identification, and Internalization on Prosocial Behavior. Journal of Applied Psychology, 71(3), 492-499. https://doi.org/10.1037/0021-9010.71.3.492

Robbins, Stephen P. \& Timothy A. Judge. (2008). Perilaku Organisasi Edisi ke-12, Jakarta: Salemba Empat.
Shore, L. M., \& Martin, H. J. (1989). Job Satisfaction and Organizational Commitment in Relation to Work Performance and Turnover Intentions. Human Relations, 42(7), 625-638. https://doi.org/10.1177/001872678904200705

Sinambela, L. P. (2016). Manajemen Sumber Daya Manusia. Jakarta: Bumi Aksara.

Supomo, B., \& Indriantoro, N. (1998). Pengaruh Struktur dan Kultur Organisasional terhadap Keefektifan Anggaran Partisipatif dalam Peningkatan Kinerja Manajerial.pdf (pp. 6184). https://doi.org/ISSN:0853 - 7046

Suweno, \& Rahadhini, M. D. (2012). Efek Moderasi Budaya Organisasi pada Pengaruh Kepemimpinan Transformasional terhadap Kinerja. Jurnal Manajemen Sumber Daya Manusia, 6(1), 58-71. http://ejurnal.unisri.ac.id/index.php/Manajemen /article/view/504 